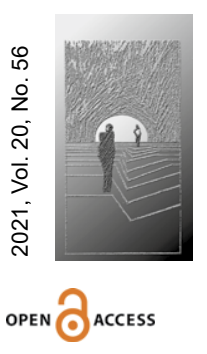

\title{
Pomiędzy Realnym podmiotu a rzeczywistością neuronauk. Historia pewnego złudzenia w tle pedagogiki ignacjańskiej
}

\section{STRESZCZENIE}

CEL NAUKOWY: Celem prowadzonych analiz badawczych jest podjęcie dyskusji wokół znaczenia procesów kognitywnych oraz teorii neuronaukowych w aspekcie pedagogiki ignacjańskiej i jej założeń dotyczących źródeł poznania człowieka w jego egzystencji.

PROBLEM I METODY BADAWCZE: Zasadniczy problem badawczy wyznacza pytanie o „żywioł myślenia" jako kluczowe zadanie dla prezentacji podmiotu i pedagogiki rozumianej jako forma zaangażowania na rzecz Innego. W prowadzonych przeze mnie rozważaniach posługuję się topologiczną, a zarazem triangulacyjną perspektywą myślenia o podmiotowości, którą wyznacza dyskurs psychoanalizy Jacques'a Lacana. W tym znaczeniu przyjmuję, że triangulacja wyznacza logikę przyczynowości dyskursów pedagogicznych.

PROCES WYWODU: Przedstawiona zostanie perspektywa badań osadzonych w paradygmacie krytycznym ukazująca triadę dyskursu osadzoną w kontekście gier językowych, neuronauk oraz pedagogii ignacjańskiej.

WYNIKI ANALIZY NAUKOWEJ: Analiza pola badawczego oraz pola poznawczego wskazuje na konieczność zachowania równowagi między poszczególnymi dyskursami, by nie doprowadzić do uprzedmiotowienia dyskursu o podmiocie.

WNIOSKI, INNOWACJE, REKOMENDACJE: Istnieje potrzeba dynamizowania działań podmiotu dla utrzymania równowagi między poszczególnymi ogniwami jego egzystencji.

$\rightarrow$ SŁOWA KLUCZE: PEDAgogia IgNACJAŃsKa, NeURONAUKI, PSYCHOANALIZA, PODMIOT, TOPOLOGIA 


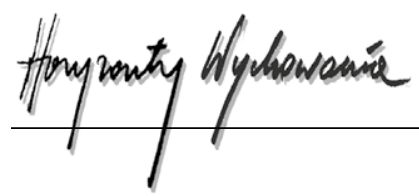

ABSTRACT

Between the Reel Subject and the Reality of Neuroscience. The History of a Certain Illusion in the Background of Ignatian Pedagogy

RESEARCH OBJECTIVE: The aim of the research analyses is to start a discussion on the importance of cognitive processes and neuroscientific theories in the aspect of Ignatian pedagogy and its assumptions regarding the sources of human cognition in his existence.

THE RESEARCH PROBLEM AND METHODS: The main research problem is determined by the question of the "element of thinking" as a key task for the presentation of the subject and pedagogy understood as a form of commitment to the Other. In my reflections, I use the topological and at the same time triangulatory perspective of thinking about subjectivity, which is determined by the discourse of psychoanalysis of Jacques Lacan. In this sense, I assume that triangulation determines the logic of the causality of pedagogical discourses.

THE PROCESS OF ARGUMENTATION: The perspective of research embedded in a critical paradigm allowing for a triad of discourse grounded in a context of language games, neurosciences and Ignatian pedagogy will be presented.

RESEARCH RESULTS: The analysis of the research field and the cognitive field indicate the need to maintain a balance between individual discourses in order not to lead to the objectification of the discourse about the subject.

CONCLUSIONS, INNOVATIONS, AND RECOMMENDATIONS: There is need to dynamize subjective actions in order to maintain a balance between the individual links of his existence.

\section{$\rightarrow$ KEYWORDS: IGNATIAN PEDAGOGY, NEUROSCIENCE, PSYCHOANALYSIS, SUBJECT, TOPOLOGY}

\section{Wprowadzenie $^{1}$}

Prezentowany tekst ma za zadanie przedstawienie rozważań oscylujących wokół rozumienia procesów kognitywnych oraz teorii neuronaukowych w aspekcie znaczenia pedagogii ignacjańskiej i jej założeń dotyczących źródeł poznania człowieka w jego egzystencji. Argumentacja, którą posługuję się w tekście, podąża za tropem badań Józefa Bremera SJ. Wywodzi się zatem od rekonstrukcji myśli Wittgensteina dla filozofii edukacji i pedagogiki w aspekcie jego gier językowych, by następnie przejść do recepcji

\footnotetext{
${ }^{1} \mathrm{~W}$ artykule posługuję się pojęciami zaczerpniętymi z psychoanalizy Lacanowskiej, stosując specyficzny zapis pojęć, które odnoszą się do matemów zastosowanych w topologii lub reprezentują kategorie pojęciowe niosące $w$ sobie znaczenie nadane przez Lacana. $Z$ tego powodu wszystkie pojęcia Lacanowskie zapisane są kursywą i jeżeli są matemami, pisane są dużą literą (Węc, 2015).
} 
neuronauk jako idei organizującej współczesny dyskurs humanistyczny i społeczny. W topologicznej triangulacji wyznaczającej logikę przyczynowości podejmowanego przeze mnie dyskursu pedagogicznego znajdują się zatem: gry językowe, neuronauki i pedagogia ignacjańska. Przyjmuję, że w tym zawęźleniu „gra językowa” reprezentuje działanie podmiotu i jego sposób życia, przy czym odniesienie mówienia do działalności jest powiązane ze społecznym kontekstem wytwarzania znaczenia (Wittgenstein, 1998). Drugą płaszczyznę rozważań wyznacza popularność neuronauk generująca niebagatelne etyczne niebezpieczeństwa dla funkcjonowania podmiotu. Kluczowym punktem rozważań staje się otwarcie pola do poszukiwania inspiracji w pedagogii ignacjańskiej wywodzącej się od modus parisiensis poprzez ratio studiorum po program magis. Przyjęta przeze mnie perspektywa poznawcza ma na celu poszukiwanie innej niż instrumentalizującej i funkcjonalnej problematyzacji rozwoju człowieka, by w efekcie zachęcać pedagogów do podjęcia prób konceptualizacji myślenia o podmiocie jako bycie ulokowanym w swej egzystencji pomiędzy logiką odpowiedzialności a logiką emancypacyjną ${ }^{2}$. Pedagogia ignacjańska pozwala również na przyjęcie Lacanowskiej perspektywy rozumienia relacji podmiotu do Innego ${ }^{3}$ i Innego do podmiotu z uwzględnieniem działania pragnienia jako niezbędnego czynnika konstytuującego byt człowieka.

Prowadzone rozważania mają charakter badań spekulatywnych wywodzących się z badań krytycznych, które po etapie badań demaskacyjnych (zrealizowanych przez Bremera) osadzają dyskurs w polu badań postkrytycznych. Badania postkrytyczne pozwalają na afirmację wizji podmiotu prowadzącej do inicjacji jego działań osadzonych w przestrzeni wolności i uznania (Zamojski, 2014), której źródło odnajduję w pedagogii ignacjańskiej. Wychodzę również z założenia, że egzystencja podmiotu zależy nie tylko od jego sprawczości, ale również od jego bierności. Jedocześnie kieruję się przekonaniem, że podmiot bierze odpowiedzialność za to, co może zrobić, i z czego z jakichś powodów rezygnuje, w efekcie przyjmując postawę afirmacyjną wobec świata. A zatem perspektywa badań postkrytycznych daje szansę na konfrontację założeń neuronauk z tym, co reprezentuje rozumienie postprawdy w horyzoncie filozofii spekulacyjnej. Przyjęty paradygmat badań spekulacyjnych można potraktować jako swoistą prowokację pozwalającą uruchomić interpretację osadzoną w ramach Lacanowskiej topologicznej triangulacji - w tym wypadku mającą swe źródło w ćwiczeniach duchowych prowadzących do ćwiczeń z myślenia, by uruchomić żywioł myślenia. Ostatecznie chodzi o pewną intelektualną grę językową prowadzącą do przekroczenia horyzontu rozumu instrumentalnego

2 Jako logikę odpowiedzialności przyjmuję tu stosunek podmiotu do budowania aktywnej relacji ze światem, a logikę emancypacyjną jako podmiotowe próby wyzwalania się z różnych form opresji świata społecznego (Zamojski, 2020).

${ }^{3}$ W Lacanowskiej terminologii inny pisany od małej litery jest zwykłym, podobnym do podmiotu człowiekiem (sąsiadem), Inny pisany od dużej litery to ten, który jest znaczącym (ważnym), gdyż wyznacza kierunek pragnienia podmiotu. W tym znaczeniu Inny to funkcja, a nie konkretna osoba. Inny związany jest z wieloma znaczeniami i odnosi się do czegoś obiektywnie istniejącego w sferze symbolicznej poza podmiotem, ale co ma na podmiot wpływ. 


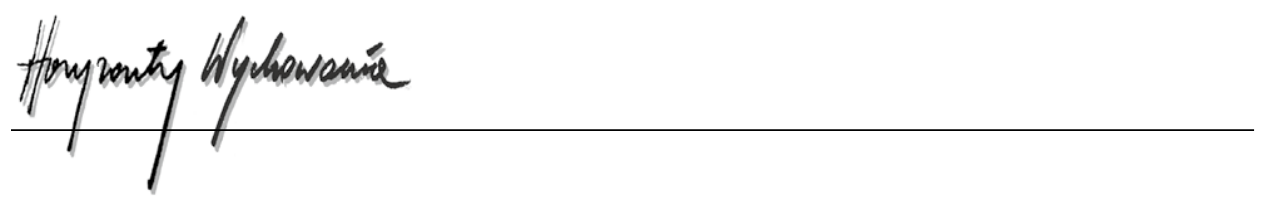

oraz wyjście poza tendencję instrumentalizowania człowieka jako takiego w sprzeciwie wobec podporządkowania podmiotu władzy biologicznych determinantów.

\section{Pedagogia ignacjańska w procesie dynamizacji rozwoju podmiotu}

Inspiracją dla prowadzonych tu rozważań staje się pedagogia ignacjańska ze swym założeniem stwarzania w relacji międzypodmiotowej warunków do ciągłego wzajemnego oddziaływania między doświadczeniem, refleksją i działaniem. Zakładanym celem ma być zatem uwrażliwianie na własne doświadczenia, postawy i opinie bez narzucania idei obcych podmiotowi. Przyjmuję, że wychowanie w szkołach jezuickich dąży do przemiany patrzenia młodych na samych siebie i innych ludzi, na struktury i systemy społeczne, na wspólnotę ludzką i całe stworzenie. Jak możemy przeczytać w Pedagogie Ignatienne Approches Concretes (b.d.), owocem prawdziwego wychowania jezuickiego powinna być radykalna przemiana nie tylko zwykłego myślenia i działania, ale też sposobu życia w świecie ludzi kompetentnych, odpowiedzialnych i wrażliwych, szukających większego dobra w tym, co można zrobić w dziedzinie wiary i sprawiedliwości dla polepszenia jakości życia. Niezbywalną ideą pedagogii ignacjańskiej jest założenie wolności podmiotowej pozwalającej na podążanie drogą umożliwiającą pełny, osobowy wzrost i rozwój. Idea ta rozpowszechniona przez ojca Pedro Arrupe, a następnie pogłębiona przez ojca Petera Hansa Kolvenbacha, wyraża się w dążeniu do osiągnięcia

(...) pełnego rozwoju intelektualnego ucznia według zdolności danych mu przez Boga, ale jego celem nigdy nie było jedynie gromadzenie wiadomości lub przygotowywanie się do zawodu a pełny wzrost osoby, prowadzący do działania przenikniętego duchem i obecnością Jezusa Chrystusa, Syna Bożego, Człowieka-dla-innych (Kolvenbach, 1989, za: Ignatian pedagogy. A practical approach, (b.d.), s. 5).

Tak więc pedagogia ignacjańska jest drogą, na której nauczyciele towarzyszą uczniom w ich wzroście i rozwoju; może być pojmowana jako rodzaj sztuki i nauki o nauczaniu, ukazującej światopogląd i wizję ideału wychowywania podmiotu podporządkowanego indywidualnej trosce o każdego ucznia.

Z perspektywy topologicznej logiki dyskursu na szczególną uwagę zasługuje model ignacjański i relacja nauczyciel - uczeń, które mogą zostać uznane za reprezentację Lacanowskiego węzła boromejskiego wraz z wyeksponowaną triangulacją „pierwszego, drugiego i trzeciego Innego” 4 eksponującego „podstawowy aspekt ignacjańskiego modelu Ćwiczeń duchownych" (Charmot, 1943). Model ten realizowany jest w triadzie

\footnotetext{
${ }^{4} \mathrm{~W}$ modelu ignacjańskim przedstawiającym relację nauczyciel - uczeń znajduje się: rekolekant-uczeń, Bóg-prawda, nauczyciel-kierownik. Z uwagi na założenia metodologiczne przyjmuję enigmatyczną pozycję Innego.
} 
DOŚWIADCZENIA, REFLEKSJI oraz DZIAŁANIA przy założeniu dynamicznego procesu uczenia i uczenia się ${ }^{5}$.

\section{Żywioł myślenia: pomiędzy logiką ćwiczeń duchowych i ćwiczeń w myśleniu}

Analiza założeń ćwiczeń duchowych powala w pewnym sensie na nawiązanie do pojęcia ćwiczenia w myśleniu wprowadzonego przez Hannah Arendt (2011), która podkreślała eksperymentalny charakter ćwiczeń mających na celu utrzymywanie podmiotu w żywiole myślenia. Perspektywa ta wydaje się istotna w odniesieniu do rozwijanych przez Bremera analiz dotyczących zagadnień neuronauk. Kluczowa jest tu konstytuująca się wiedza o myśleniu, ukazująca proces wykonywania operacji logicznych, przetwarzania informacji, przekształcania schematów poznawczych oraz dokonywania interpretacji (Guilfort, 1978). Jeżeli przyjmiemy, że myślenie jest pewnym egzystencjalnym stanem, pewnym specyficznym sposobem bycia, który można opuszczać, rezygnując z niego, albo można „utrzymywać się w nim”, postawimy za Heideggerem pytanie „co znaczy myśleć?” (Heidegger, 1983, s. 237). W efekcie staniemy przed dylematem, co uda nam się zrozumieć, próbując refleksyjnie doświadczać naszego bycia w myśleniu (Zamojski, 2020). Heidegger formułując „trzy kroki” na drodze swego myślenia, umieszczał je w polu pytań: o sens, prawdę oraz miejsce Bytowania, które sam określa „topologią Bytowania" (Topologie des Seyns/Topology of Be-ing) (Heidegger, 1997) ${ }^{6}$. Sprawę jednak pedagogicznie skomplikuje Robert Kwaśnica, stwierdzając, że myślenie nie jest tym samym, co wiedza, gdyż częściej wydaje się nam, że coś wiemy, niż rzeczywiście myślimy (Kwaśnica, 2003, s. 291). O ile zatem Kwaśnica zakłada, że myślenie jest poszukiwaniem wiedzy, a każde postawione pytanie domaga się swojej odpowiedzi, to jednak kiedy dana odpowiedź będzie ostatecznie satysfakcjonująca, myślenie ustanie. Czy możemy zatem uznać, że w jakimś sensie wiedza nas usypia? Powodując, że jakaś część świata zostaje opisana, oswojona i jako taka pozostaje „pod kontrolą”, nie prowokując nas dalej do wysiłku myślenia (Zamojski, 2020).

\section{Neuronauki w procesie instrumentalizacji podmiotu}

Troskę o autonomię podmiotu oraz dynamikę rozwoju w perspektywie podejmowanego przez podmiot wysiłku myślenia znajdujemy u przywołanego już wcześniej przedstawiciela pedagogii ignacjańskiej ojca Józefa Bremera. Ten współczesny jezuicki filozof

\footnotetext{
${ }^{5}$ Analiza tego modelu w perspektywie Lacanowskiego modelu topologicznego węzła boromejskiego z pewnością wyznacza obszerne pole badawcze, którego recepcja tu nie jest możliwa.

${ }^{6}$ Szczegółowa interpretacja topologii Heideggera znajduje się w książce Malpasa Heidegger's Topology: Being, Place, World (Malpas, 2006).
} 


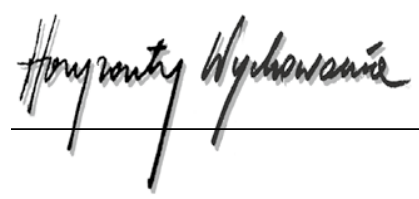

i pedagog zaprosił nas do spektakularnych ćwiczeń w myśleniu - upominając się zarazem o ćwiczenia duchowe - dbając, by żywioł myślenia uobecniał się podczas podróży przez hermeneutycznie skonstruowane pole badawcze po epistemologiczną analizę kognitywistycznie ujętego procesu poznania wszystkiego, co reprezentuje „neuro-coś-tam”. W pracy Interdyscyplinarne znaczenie neuronauk (Bremer, 2016) możemy prześledzić wysiłek badawczy nad szeroko rozumianymi neuronaukami, które zdominowały w ostatnich latach nie tylko badania z obszaru nauk biologicznych, ale bezpardonowo zawłaszczyły dyskursy nauk humanistycznych i społecznych ${ }^{7}$. Mózg stał się swoistym fetyszem, który w porządku Wyobrażeniowego ${ }^{8}$ pojmowania funkcjonowania człowieka doprowadził do potencjalnego „zredukowania indywidualnego podmiotu do czysto biologicznego konstruktu” (Bremer, 2016, s. 185). W perspektywie rozważań o podmiocie i Innym ciekawe staje się pytanie o wolną wolę oraz o dylematy zawarte w pytaniu: „czy Bóg jest urojeniem, czy jest On ubocznym produktem ludzkich procesów mózgowych, czy też w procesach tych są przetwarzane jakieś realne spostrzeżenia czegoś transcendentnego?" (Bremer, 2016, s. 13). Podążając za tym żywiołem myślenia, przyjmując perspektywę gier językowych Wittgensteina oraz Lacanowską koncepcję podmiotu oraz Innego, stajemy jako refleksyjni badacze przed koniecznością poradzenia sobie z dylematem: czy podmiot i Inny jest również urojeniem wynikającym z bezwzględnego działania porządku Realnego, w którym bez wątpienia zanurzony jest mózg? W tym sensie warto podjąć próbę rozwikłania zagadki, co by było, gdy Homo faber stał się Homo neurobiologicum. Czy potencjalnie pożądana identyfikacja każdego człowieka do Homo faber jako bytu mówiącego zamieniłaby się w mityczną identyfikację podporządkowaną działaniu Realnego? Bez wątpienia byłaby to neuroidentyfikacja, której nie można uchwycić w realnym życiu z powodu czasowej niesprawdzalności reprezentującej nie tylko immanentny wymiar hic et nunc. By uniknąć zatem groźby zapanowania Realnego nad podmiotem - jak dzieje się to w psychozie - niezbędna staje się identyfikacja z bytem mówiącym, pozwalająca żyć między ludźmi. Jest to możliwe dzięki temu, że uruchomiony zostaje porządek Symboliczny, w którym reprezentowany jest łańcuch znaczących umożliwiający podmiotowi przyjęcie imienia pochodzącego od symbolicznego innego człowieka (Węc, 2012). Problemem stają się więc neuroidentyfikacje ulokowane w polu Wyobrażeniowego jako swoiste maskarady ${ }^{9}$ zanurzone w fantazmacie

\footnotetext{
${ }^{7}$ Przykładem może być np. neurodydaktyka czy neurokosmologia.

${ }^{8}$ Lacan sformułował koncepcję trzech porządków psychicznych, przyjmując, że porządek $W y$ obrażeniowy jest miejscem dochodzenia do sensu, porządek Symboliczny jest polem dwuznaczności, a Realne jest miejscem wszystkiego, co jest niemożliwe do pomyślenia. Istotą podejmowanych rozważań jest porządek Realnego reprezentujący konstrukt, o którym nie możemy nic powiedzieć, gdyż jego działanie jest nie do przyjęcia wobec logiki racjonalności, a gdy już pojawi się bez zapowiedzi w życiu podmiotu - nieuchronnie pozostawi po sobie traumę (Węc, 2015). W tym sensie neuronauki poprzez przewartościowanie znaczenia mózgu próbują „zapanować” nad działaniem Realnego, dając pozór, że człowiek może panować nad samym sobą.
}

${ }^{9}$ Za maskaradę uważam tu badanie mózgu (jego neroobrazaowanie) jako reprezentowanie pewnego rodzaju „naukowego obłędu czy naiwności naukowej” prowadzącej perwersyjnie „nie tylko 
wyprodukowanym poprzez próby biologicznie zdeterminowanego myślenia o człowieku jako zinstrumentalizowanym bycie. A zatem zostajemy złapani w pułapkę naukowo narzuconego obrazu, z którego wykluczono spojrzenie Innego. W takim rozumieniu maskarada staje się efektem interpretacji neuronauk jako sfery skrajnie (nie)zróżnicowanej. Można również powiedzieć: sfery masowej - podporządkowanej temu, co określone zostaje jako „nic”. Zarazem jednak to „nic” jest Lacanowskim obiektem a, który jako wzniosły obiekt neuroideologii w swym anamorficznym przekształceniu musi zostać dostrzeżony „z ukosa”, by rozpoznać maskaradę, ale również i po to, by nie poddać się oszustwu obrazu, w którym widzenie nie oznacza spojrzenia (Žižek, 2001), myślenie nie oznacza myślenia, a mówienie nie oznacza mówienia.

\section{Historia pewnego złudzenia - neurodydaktyczne mistyfikacje}

Konkludując, podejmę ryzyko uznania, że neurobiologiczne złudzenia mają swe źródło w instrumentalizacji rozumu, który w obszarze myślenia o procesach edukacyjnych niesie za sobą groźbę etycznego zaniedbania prowadzącego do wykluczenia Innego oraz zdeprecjonowania całej sfery duchowej podmiotu. Groźba ta ujawnia się również wtedy, gdy wiedza o mózgu wprowadzająca pewność powstawania obszarów poznawczych czy reaktywnych działań podmiotu jedynie uzależnionych od poziomu i rodzaju neuroprzekaźników wyklucza nieświadome procesy i w efekcie prowadzić może do nieetycznej bezmyślności. Nie można pominąć faktu, że jesteśmy świadkami próby wykluczenia samego podmiotu zarówno ze sfery odpowiedzialności (sprawstwa) jak i jego emancypacji (wolności) w oscylacji pomiędzy jego obecnością i (nie)obecnością oraz jego świadomym a nieświadomym bytem.

Wydaje się, że neuronauki uruchomiły nowy wymiar pojmowania obecności oraz (nie)obecności podmiotu już nie tylko poprzez jego symboliczne wykluczenie, ale również w odniesieniu do jego realnego bycia wobec Innego - również obecnego bądź (nie)obecnego, choć pozornie niewykluczonego. W perspektywie topologicznego ujmowania biegu życia podmiotu człowiek musi wiązać się z Innym, by odnaleźć się w dialektyce pragnienia, albo musi pożądać przedmiot a będący w posiadaniu Innego, by odnaleźć źródło satysfakcji (Węc, 2015). Nie oznacza to jednak, że Inny może zawłaszczyć ten enigmatyczny przedmiot a, który reprezentuje w przypadku neuronauk mózg. A więc nie jest tak, jak słyszymy od neurodydaktyków, że mózg jest miejscem pracy nauczyciela, gdyż w rzeczywistości nie mają do niego żadnego dostępu. Z tego też powodu warto w procesie ćwiczeń duchowych, ćwiczeń do myślenia czy wreszcie żywiołu myślenia przyjąć wyzwanie, które dostrzegam w pedagogii ignacjańskiej jako formowanie zadania do myślenia. Celem takiej formacji byłoby uchronienie podmiotu przed niemyśleniem reprezentującym nową formę zniewolenia podmiotu zwalniającą

do badania obserwowalnego, materialnego świata (obejmującego nasze ciało i mózg), lecz także do wewnętrznego świata, tworzonego przez umysł i świadomość" (Bremer, 2016, s. 8). 


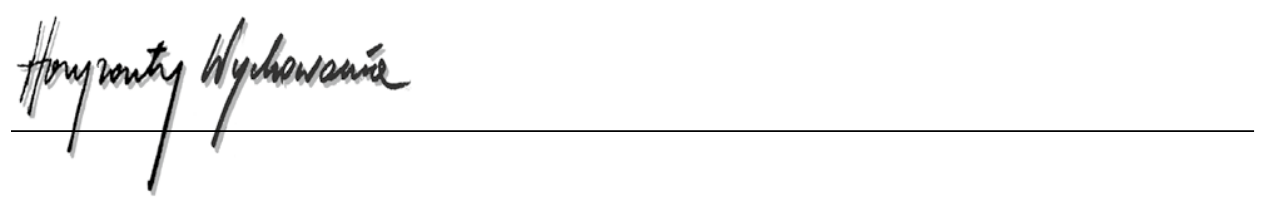

go z odpowiedzialności oraz pozbawiającą go możliwości emancypacji. Koniecznością staje się również dostrzeżenie, że niebezpieczeństwo tkwi w instrumentalizacji rozumu oraz wzbudzaniu nieufności wobec tzw. prawd absolutnych wyrażanych w schematach, wzorcach, modelach czy algorytmach pozornie myślących za podmiot. W takiej samej mierze należy być ostrożnym w nierefleksyjnym przyjmowaniu zewnętrznych praw zwalniających podmiot z odpowiedzialności za jego działanie i myślenie, ustanawiając posłuszeństwo wobec naukowych mistyfikacji dających pozór dostępu do pewności i prawdy o podmiocie. W tym również sensie zastosowana przez mnie topologiczna triangulacja ukazuje podmiot poddany działaniu trzech porządków Realnego, Symbolicznego oraz Wyobrażeniowego, od których zależy jego ukonstytuowanie, niosąc nadzieję, że jego rzeczywistość nie będzie zdominowana przez neuronauki. Jeżeli bowiem uznamy, że rzeczywistość podmiotu wyznaczać będą procesy kognitywistyczne i neurobiologiczne, ryzykujemy, że człowiek zostanie schwytany w pułapkę bycia doskonałym, ulegając społecznie konstruowanej narracji mającej w założeniu prowadzić do sformatowania tożsamości poprzez wymóg aktywności, kreatywności czy użyteczności. Mamy zatem do czynienia z reprezentacją myślenia magicznego odsłaniającą ambiwalentność i zarazem niemożliwość realizacji naiwnego życzenia wyrażanego poprzez równolegle generowane neurobiologiczne mistyfikacje. Podmiot musi się obronić przed zakusami sprowadzenia go do „nośnika” czy reprezentanta mózgu w takiej samej mierze, jak powinien zawalczyć, by jego egzystencja nie została pozbawiona immanentnych wartości samopoznania oraz doświadczania sprawczości i wolności.

\section{BIBLIOGRAFIA}

Arendt, H. (2011). Między czasem minionym a przyszłym. Osiem ćwiczeń z myśli politycznej (M. Godyń i W. Madej, tłum.). Wydawnictwo Aletheia.

Bremer, J. (2016). Interdyscyplinarne znaczenie neuronauk. Akademia Ignatianum, Wydawnictwo WAM.

Charmot, F. (1943). La pédagogie des Jésuites. Ses principes. Son actualité. Spes.

Guilford, J. (1978). Natura inteligencji człowieka (B. Czarniawska, W. Kozłowski i J. Radzicki, łłum.). Państwowe Wydawnictwo Naukowe.

Heidegger, M. (1983). Co znaczy myśleć? (J. Mizera i J. Tischner, tłum.). W: Z. Kuderowicz (red.), Filozofia współczesna (t. 1, s. 297-309). Wiedza Powszechna.

Heidegger, M. (1997). Seminare („Gesamtausgabe”, t. 15). Vittorio Klostermann.

Ignatian pedagogy. A Practical Approach. (b.d.). http://www.sjweb.info/documents/education/ pedagogy_en.pdf

Kwaśnica, R. (2003). Wprowadzenie do myślenia o nauczycielu. W: Z. Kwieciński i B. Śliwerski (red.), Pedagogika. Podręcznik akademicki (t. 2, s. 291-323). Wydawnictwo Naukowe PWN.

Malpas, J.E. (2006). Heidegger's topology: being, place, world. Massachusetts Institute of Technology.

Pedagogie Ignatienne approches concretes. (b.d.). http://docplayer.fr/41646532-Pedagogie-ignatienne-approches-concretes.html

Węc, K. (2012). Psychoanaliza w dyskursie edukacyjnym. Radykalność humanistyczna teorii i praktyki pedagogicznej. Konteksty nie tylko Lacanowskie (wyd. 2). Wydawnictwo Adam Marszałek. 
Węc, K. (2015). Granice i transgresje współczesnego wychowania. Psychoanaliza wobec kryzysu podmiotu. Kontestacyjny wymiar pedagogiki krytycznej i jej praktyczne implikacje (wyd. 2). Wydawnictwo Adam Marszałek.

Węc, K. (2018). Surogaty tożsamości wobec genealogii i rozwoju podmiotu. Pomiędzy mimetyczną funkcją anamorfozy a figurą Innego. Edukacja Międzykulturowa, 9(2), 131-149.

Wittgenstein, L. (1998). Znaczenie słowa (A. Lipszyc, tłum.). W: L. Wittgenstein, Niebieski i brązowy zeszyt. Szkice do „Dociekań filozoficznych”. Spacja.

Zamojski, P. (2014). Od demaskacji ku budowaniu. Po-krytyczna perspektywa badań pedagogicznych. Teraźniejszość - Człowiek - Edukacja, 3(67), 7-22.

Zamojski, P. (2020). Utrzymywanie się w żywiole myślenia jako zadanie pedagogiki. Filozoficzne Problemy Edukacji, 3, 61-74.

Žižek, S. (2001). Melancholia i akt etyczny (M. Szuster, tłum.). Res Publica Nowa, 10, 94-109.

\section{Copyright and License}

This article is published under the terms of the Creative Commons Attribution - NoDerivs (CC BY- ND 4.0) License http://creativecommons.org/licenses/by-nd/4.0/ 